\title{
Nepal's Pro-poor Leasehold Forestry Program: Processes, Policies, Problems and Ways Forward
}

\author{
H.K. Laudari ${ }^{1}$ and T. Kaini \\ Corresponding author: H.K. Laudari \\ Email: hklaudari@gmail.com
}

\begin{abstract}
The pro-poor leasehold forestry program has put forth the ultra-poor's livelihood agenda in the natural resource management regime and tried to liberate the poor from complex poverty trap through manipulating and institutionalizing the local resources. This paper is based on review of published and unpublished documents, direct field observation of leasehold forest user groups and discussion with concerned stakeholders and line agencies working in pro-poor leasehold forestry program. The paper has explicitly tried to dig out the institutional, field level and legal issues, and put forwarded some ways out. The unclear land tenure right and use rights of conserved forest trees have created misunderstanding to the beneficiaries that ultimately pushed the pro-poor leasehold forestry program towards uncertainty. Both technocratic approach and supply-driven implementation of the program have created misunderstanding while deliberating the program, and resulted low participation, weak institution and little internalization at community level. The explicit learning-oriented approach both in policy making and program designing is central to achieve the dual objectives of program: environmental amelioration and poverty reduction.
\end{abstract}

Key Words: Pro-poor leasehold forestry, Tenure right, Supply driven, Learning oriented approach, Natural Resource Management

\section{Introduction}

Forest resources are increasingly recognized for enhancing the livelihood of forest dependent poor in developing countries without jeopardizing the natural resource base (Carney, 1998). Leasehold forestry is a devolution strategy that shifts both control and authority over natural resources from centre down to local communities (Fisher, 1998; Agrawal and Ostrom, 1999), and seeks to address livelihood issue through subsequent resource conservation (Chhetri, 2006). The paradigm shift of Nepal's forestry sector policy from strict protection to livelihood based participatory resource conservation has oened

Ministry of Forest and Soil Conservation, Kathmandu 
an avenue to institutionalize the various participatory forest management systems. Over past three decades, six different participatory forest management modalities have been implemented in Nepal as a strategy of conserving natural resources and poverty reduction: Community Forestry, Leasehold Forestry, Watershed Management, Collaborative Forest Management, Integrated Conservation and Development Program, and Buffer Zone. Among these, leasehold forestry for poor is a new frontier that tries to address the overall livelihood agenda of ultra-poor at household level through the manipulating and institutionalizing the local resources. Many scholars show the resurgence of critique on various aspects of Propoor Leasehold Forestry (PLF) program though the leasehold forestry program casts out positive impact on the livelihood of ultra poor.

\section{Materials and Methods}

This paper has been prepared mainly by studying different policy and implementation reports. Both published and unpublished books and documents including project documents and progress reports have been thoroughly reviewed for the base of this paper. Previous studies and research findings have also been compared to make the paper more impressive and meaningful. Moreover, field observation and consultation with leasehold forest users and concerned stakeholders have also been done to incorporate the ideas and knowledge regarding PLF.

\section{Results and Discussions}

\section{Pro-poor Leasehold Forestry: Process and Current Achievements}

It is often claimed that community forestry policy and program with its limited focus on exclusive use right on forest resource and benefit sharing to poor is the basis of emergence of household-focused PLF program. It is a new kind of participatory forest management modality introduced in 10 districts in 1992 for 10 years as a Hills Leasehold Forestry and Forage Development Project (HLFFDP) by the government of Nepal with financial support from International Fund for Agricultural Development (IFAD), Asian Development Bank and Dutch funded Food Agricultural Organization (FAO). Based on the achievements of HLFFDP, the government of Nepal continued leasehold group formation and supports from its own financial sources as Bridging Phase for three years (2002-2005). In 2005, IFAD again continued support and current Leasehold Forestry and Livestock Program (LFLP) was launched for the period of 8 years in 22 hill districts with dual goals of reducing poverty of 44,300 poor families through increased forest and livestock production and ensuring environmental amelioration. In the mean time, the success and results by IFAD funded projects have attracted other donor funded projects as well to help support forest dependent poor through leasehold forestry. Moreover, IFAD funded other project named "Western Upland Poverty Alleviation Project-WUPAP" also followed the concept and is supporting leasehold forestry even in mountains like Humla, Jumla and other districts.

Keeping the generic idea same, the projects have implemented differently according to the local situations and needs. In addition to hand over of leasehold forests and post-formation 
support, Livelihood for Forestry Program has practiced land allocation also for poor inside leasehold forests for raising income from grass, fodder and NTFPs. Biodiversity Sector Program for Siwaliks and Terai (BESEP-ST) implemented the concept in Terai districts with promoting income generating activities including NTFPs. In addition, FAO's Technical assistant for LFLP, funded by the government of Finland has been piloting the same concept in four districts namely Palpa, Nawalparasi, Sayangja and Gulmi in an integrated way focusing on resource pooling from other development partners. Thus, presently, the PLF concept has been implemented in all three geographic regions of Nepal i.e. in the Terai, Mid-hill and Mountain region. With all these projects and programs, currently in Nepal there have been more than 7,000 LFUGs managing over 40,000 ha of LFs through active involvement of over 62,000 poor families.

Basically, PLF is similar with other participatory forest management programs like community forestry as such forest users are organized in a group and are given rights and responsibilities to manage a patch of forest. Moreover, it is targeted to the community groups below poverty line with threshold level identified by National Planning Commission (NPC): household with land less than 0.50 ha and/or an annual income less than NRs. 6,100 . According to existing policy and practices, only shrub land, land recovered from forest encroachers and natural calamities, forests with less than $20 \%$ crown cover, and areas vulnerable to soil erosion are potential areas for leasehold forestry. Leasehold Forest Users Groups (LFUGs) are arranged in such a way that 5 to 10 members in each LFUG should possess $0.70-1.00$ ha of forestland (below 2000m) per HHs. If the communities are not willing to take patches of forest as community forestry, only then PLF process proceeds ahead. PLF process: group formation, preparing operational plan, filing application, getting approval from concerned authority and land development is done by LFUGs themselves as well as seek support from forestry staffs. The leasehold forestry for poor is leased for 40 years and its tenure could be extended for another 40 years if the leaseholders manage the leasehold properly. The royalty is exempted to leasehold forestry for poor. Not only has the PLF program had livestock and forage production, it also has another livelihood options like saving credits and forest based micro enterprises. PLF program has mainly two governmental implementing agencies: Department of Forest and Department of Livestock Service.

\section{Legal backup}

Nepal's first National Forestry Plan (1976) made the provision of leasing government forest area to individual or community for raising tree and clearly defined tenure rights over these forest resources to caretaker, but the plan was silent on PLF. In Master Plan for the Forestry Sector (MPFS) 1988, the first strategic document of forestry sector, leasehold forestry came under the heading of 'National and Leasehold Forests' and considered as a second priority after community and private forest. The Master Plan acknowledged that any part of national forest shall be managed and developed as a leasehold forest through providing forest land in a lease to private sector and industries for producing raw material. However, leasehold forest for poor had not been visualized in MPFS. Forest Act of 1993 
has clearly mentioned that forest could be leased to the corporate bodies, industries (forestbased or eco-tourism based) and communities but has not envisioned forest for poor people. But, Forest Regulation (1995), strong legal backing document for PLF, has come out with making a special provision of leasing out forests to disadvantaged groups.

The contribution made by leasehold forest for poor has clearly been stated in Agricultural Perspective Plan (1995-2015)-increase agro-based production \& livestock development. Similarly, Agriculture Policy (2004) envisaged the provision of handing over marginal land, grazing land and unused public land as a lease land to target groups, and acknowledged the role of these lease land in poverty alleviation through production of forage, fodder, agro-forestry, medicinal and aromatic plant, NTFPs and silkworm. Likewise, NTFPs Policy (2004) has encouraged participation of poverty stricken women to cultivate NTFPs/MAPs inside leasehold forest and community forest to reap the maximum benefit.

Recognizing the role of forest for poverty reduction, Eighth Plan (1992-97) targeted 25,000 underprivileged families for benefiting from leasehold forestry program. Ninth Five Year Plan (1997-2001) acknowledged the role of agro-forestry and leasehold forest system in poverty alleviation, and committed to continue and strengthen these systems by revising existing forest policy. In addition, Tenth Plan (2002-2007) and its auxiliary, Poverty Reduction Strategy Paper (PRSP) 2002, acknowledged contribution of leasehold forestry to reduce poverty and spotlighted that leasehold forestry concept should also be implemented in community forestry. Moreover, the theme of Tenth Plan was that leasehold forestry should be extended in larger area considering the livelihood opportunities of people living below poverty line. Leasehold Forest Policy (2002), landmark legal document for PLF, has delegated the power regarding PLF process to District Forest Office and alienated mandatory submission of financial feasibility report. The policy has furthermore made the provision of benefit sharing to poor people from the old trees retained during forest handover. However, the policy has yet to be integrated into the Forest Act and Forest Regulations to materialize in the field. Likewise, Interim Plan (2007-2010) of Nepal came with the commitment of improving policies, strategies and implementation procedures in community based program through wider cooperation and coordination with different stakeholders and local institution to strengthen right, benefits and autonomy of marginal disadvantaged groups. Interim Plan Approach Paper (2010/11-2012/13) has not explicitly spelled out any strategy and working policy to be formulated and implemented to promote PLF but targeted to form certain number of LFUGs of poor and backward classes. In addition to that, it has tried to address the livelihood opportunities of poor, indigenous and ethnic, madhesi and backward people through sustainable forest management and forest based enterprise development.

\section{Issue and Problems}

It is often claimed that limited focus and contribution of other programs to poor formed an important basis for design and implement leasehold forestry program to reach more directly and effectively to poor people (Ohler, 2000). PLF is successful in achieving its dual objective: environmental rehabilitation and livelihood promotion of poor through increasing livestock 
production and rehabilitating degraded land (Ohler, 2000), saving time in collecting forest products (Douglas, 2000; Ghimire, 2000; Pandit, 2009; Sharma, 2011; LFLP, 2011), casting positive livelihood impact on poor (Niraula, 2001; Pandit 2009), improving land quality and increased diversity of plant and wildlife (IFAD, 2003; NPC, 2005; Pandit and Thapa, 2003), increasing trust between members and non-members (Pandit et al., 2008), improve human and social capital (IFAD, 2003; NPC, 2005); and managing the leasehold forestry properly (TA LFLP, 2012).

In spite of these claim of successes, there are many issues to be resolved to mainstream the approach smoothly for reducing national poverty. Following issues on different thematic areas have been emerged:

\section{Legal issues}

Pro-poor leasehold forestry in Nepal has been criticised with the apparent paradoxical notion of 'degraded land' for 'poor people" which has pushed the concept towards negativism in mass people. The legal provision is to hand over forests having crown cover up to $20 \%$. As the program is being implemented in hills, forests even with zero crowns cover i.e. barren and open land with low fertility. Leasehold forest user groups are still in confusion about the utilization aspects of forest products especially timber. In some cases, trees have attained the exploitable sizes but there is no clear provisions mentioned in policy and legal documents. So, even in some LFUGs where timber can be harvested, legal and policy constraints become problems. Moreover, PLF has not been centre of attraction to forest dependent targeted poor due to uncertainty in tenure right of land and use right of conserved forest trees after the handover of leasehold forest. In Makwanpur, Bhattarai et al (2005) found that lack of clear provisions with regard to transfer of resource tenure had created a sense of insecurity in poor especially in the Chepangs community. Similarly, land provided for 40-year leases to very poor households in most cases is highly degraded with poor soil fertility, and households have used these lands (illegally) for grazing their animals (IFAD, 2012). Therefore, Regmi et al (2008) claimed that program strategies of PLF were often incompatible with the actual livelihood strategies of poor. In this regards, Baral and Thapa (2003) considered PLF an endeavour with a good philosophy but bad institutional mechanism: program intervention (the people at the field tend not to do a good job) and the policy (which does not fully understand the dynamic nature of the people-resource interaction).

Field level difficulties have also been experienced due to unclear and contradictory legality of PLF. More specifically, if a community is ready to take over the forests as Community Forest, DFO cannot hand over the same as leasehold forestry. Bhattarai et al (2005) reported that government's ignorance to power delegation, PLF to the DFO by translating leasehold forest policy in to forest regulation, has resulted lethargic condition of PLF. Similarly, discrimination to leasehold forest over community forest has mulled over for exploring the synergy between two programs: some degree of competition between two programs for the same areas of land and forest resources (Bhattarai and Dhungana, 2005). It is difficult 
to identify the ultra poor in the field as per the criteria developed by National Planning Commission. So, the blanket criteria adopted for defining poor has created difficulties in full-fledged implementation of PLF program (Grinten and Dhakal, 1997).

\section{Institutional issues}

Institutional development (women and dalits involvement in decision making process, implementation of operational plan, record keeping, coordination and collaboration with other agencies) and rural finance aspects (regular saving, saving mobilization, loan repayment) of many groups are poor (TA LFLP, 2012). Regular follow up and capacity development of LFUGs have always been overlooked. For instance, in Kavre, Bhattarai et al (2003) found that trainings and follow-up to LFUGs were limited and thus, unable to substantially empower the poorest. The PLF program has handicapped the local institution rather than making robust and vibrant one. Therefore, some of the researchers summed up that lengthy and complex process of forest handover is not affordable to poor households, and concluded that PLF is beyond the reach of poor (Dhungel, 1997; Yadav and Dhakal, 2000). No internalization of PLF program by elite people from the same community is the major cause of conflict between leaseholders and non-leaseholders. For example, there were incidents of stealing fruits and grass, and free cattle grazing in leased land from nonleaseholder because of being alienated from leasehold forest member (Baral and Thapa, 2004). However, Singh (1997) concluded that the reason for existence of conflict in PLF was the lower involvement of civil society and lack of collaboration with community forest.

The LFUGs, formed during the period of HLFFDP, has become orphan due to lack of consistent support and follow up. Therefore, these LFUGs had grave situation and their sustainability was in question after the termination of the project (Joshi et al., 2000). It is often said that PLF is demand driven program but in reality, it is supply driven. The process of group formation within the IFAD portfolio (LFUGs, farmers groups, cooperatives, and savings and credit groups) is supply-driven and there are few self-starters. Moreover, free hand-outs of goats from many other programs, Non-Governmental Organization and Poverty Alleviation Fund are the only motivation factor for households to join the PLF program (IFAD, 2012). Technical service delivery from project staff is not sufficient to robust poor as project staffs tend to promote their own technical ideology and knowledge (Nightingale, 2005), and have limited capacity and commitment to engage in empowerment processes. Government support for goat farming and in particular to animal health services are generally weak and not satisfactory (LFLP, 2009; TA LFLP, 2011; IFAD, 2012). For instance, vaccination and drenching is not regularly practiced in LFUGs (TA LFLP, 2012).

Moreover, the need based assessment of income generating activities to be implemented in the community is often lacking. Even if the LFUGs produce forest product, it is in too small amount to satisfy market demand. Similarly, poor knowledge on marketing of products is another problem faced by LFUGs (Bhattarai and Dhungana, 2005). The rural finance status of most of LFUGs is poor. Only about $40 \%$ of the loan amounts are being used for purposes of income generating activities (TA LFLP, 2011; IFAD, 2012). The program is being 
implemented under donor funded projects and programs. In some cases, transparency of fund and expenditures has been questioned. Similarly, service delivery through government and other line agencies are mostly limited, overlapped and not significant. Thus, it is often criticized that there are more number of service delivering agencies than actual number of poor. LFUGs located in remote area are always deprived of services, and have little capacity of tapping resources from local government and agencies. LFUGs formed before the establishment of buffer zone area have become functionless and their legal validity is at jeopardy. Similarly, poor networking of LFUGs has made difficulty in raising the voice against legal hurdles as well as in knowledge sharing.

\section{Implementation issues}

It is also blamed that scattered and diluted support from old integrated projects, physical input/out-put focused government delivery system, weak monitoring and evaluation system, and unrealistic and optimistic project design has negatively influenced on PLF program's achievement (IFAD, 2012). Although, PLF program intends to target the poorest communities, many studies have shown that de facto poor leasehold forest users are left out in leasehold forestry process (Grinten and Dhakal, 1997; Joshi et al., 2000; Baral and Thapa, 2003). As a result, there are evidences where some middle class and even richer households are included in LFUGs (Bhattarai et al., 2003). Political boundary has hampered the poor people to get membership of leasehold forest. Joshi et al (2000) concluded that political boundary were the major hurdle for poor in participating PLF program. In PLF process, only degraded land is handed over, and grass and trees are grown. But in reality, grasses and trees grown in leasehold forestry would not give prompt benefit to ultra-poor rather LFUGs have to bear higher opportunity cost. Similarly, potential area to be handed over as leasehold forest is rather low as most of the accessible areas have already been handed over as community forestry. Thus, the average leasehold forest area per $\mathrm{HH}$ is 0.5 ha which is less than the expected national average 0.7ha/HH (TA LFLP, 2011) which supports that PLF is not getting the momentum as it was anticipated during program formulation. Moreover, PLF program is criticized as a too expensive program to run under loan money, transparency are lacking, considers only a small section of community, ignores wider environmental ground, output does not match with input and sustainability, a controversial issue since its inception, and compete with stakeholders (Baral, 2004).

Senior forest officer of Department of Forest (DoF) supports that few staffs in LFLP section of DoF to support, monitor and evaluate LFUGs of whole 22 districts and their frequent turn-over are the major hindrance to PLF program. Moreover, delay in disbursement of trimester budget of PLF program from NPC has hampered timely execution of program. Due to overlapping jurisdiction and status quo of livestock and forestry counterparts, field level complication has been arised while implementing pro-poor leasehold forestry program. Govermnet staff working in field accepts that with no additional staff and incentives to implement additional PLF program in districts obviously establishes the tendency of shortcutting the pro-poor leasehold forestry process, and consequently results lesser quality of output. Poverty is a dynamic process, but PLF process considers it to be 
a constant handing over degraded forest area along with 2-3 goats to escape poverty: an impracticable and immature thought. The frequent turnover of group promoters, aimed to strengthen LFUGs, is another reason for slowing down the PLF process. In addition to that, theme wise involvement of service providers in PLF program has become ineffective and inefficient rather it makes delay and difficulties in program implementation.

\section{Lesson learnt}

It is often realized that PLF program is a successful initiative in favor of poor people but in reality it has not yet been centre of attraction even to targeted beneficiaries. Therefore, the whole program is distracting from its original theme: environmental amelioration and poverty reduction. Small area of degraded forest couldn't give prompt benefits to ultrapoor rather it further degrades their livelihood. Similarly, unclear land tenure and use rights over conserved forest tree have created misunderstanding to the ultra-poor. Therefore, it ultimately challenges the objectives and legal provision of program. Both technocratic approaches and supply-driven implementation of program has created confusion during deliberating the program, and resulted low participation and internalization at community level. Poverty reduction is very complicated process and cannot be lessened only from contribution of one sector rather it needs functional collaboration and consultation amongst multi stakeholders working in poverty theme. Moreover, experiences gained during the program's implementation are bases for policy formulation and program design. Further, local level deliberation is needed right from the program formulation to implementation to maximize benefit and lessen conflict amongst LFUGs.

\section{Ways forward}

The explicit learning-oriented approaches both in policy formulation and program design are highly instrumental to make PLF program tractable within its original motive. Moreover, the issues and gaps existed in PLF program should be timely revised and revisited through amending the concerned policy and changing operation modality. The trend of handing over degraded land to poor should be switched towards well-stocked forest with larger area. Similarly, the PLF program should be implemented all districts of country by making legal provision of leasing out under-utilized public land and land belonging to religious organization/institution. Equal legal recognition of leasehold forest and community forest, and clarity on provisioning LFUGs inside protected area should be made by revisiting and revising concerned law and policy. In addition, legal recognition of LFUGs network is vital for leaseholder to bargain against legal matters, pool the local resources from others agencies, knowledge management and sharing.

Pro-poor policies do not work alone unless appropriate implementation mechanisms are instituted and local institutions adequately internalize it. Context-specific and locallynegotiated criteria for identification of poor and on-spot wider facilitation of program to beneficiaries are crucial to leverage PLF program to the household level. Moreover, institutional reform accompanied by capacity building and technology transfer is highly 
imperative to make the local institution more vibrant and robust. For instance, regular support and backstopping to LFUGs and buy back guarantee and marketing of products indispensable for the successful implementation of PLF program. In addition, forest based micro-enterprises and income generating activities should be implemented only after assessing the real need of beneficiaries. The PLF concept should be integrated with other development projects and programs to ensure adequate resources pooled for sustainability of small leaseholder poor groups. The concept should also be mainstreamed in the strategic and implementation guidelines of local governments i.e. DDC and VDC. Likewise, multistakeholder body should be formed at district level to manage, supervise and implement PLF program.

To address the problem of food security, special program should be launched like agroforestry practices as well as cropping of short rotational crop like pineapple, banana and broom grass etc. Service provider involved in facilitating PLF program should be orientated on its legal and implementation procedure to smooth path in designed way. Similarly, timely disbursement of trimester budget of LFLP from NPC is precondition for effective and efficient implementation OF PLF program. Intensive social mobilization support should be provided to the passive and medium category groups at least for three years so as to make them active. Further, special consideration should be imparted during planning and budgeting of income generating activities from NTFPs and MAPs along with coaching on planting technique who have poorly managed leasehold forests. Further, Large number of LFUG members should be trained and better mobilized to deliver animal health services in nearby clusters. To mainstream poverty reduction agenda in community based natural resource management regime, PLF program should intensively be incorporated in other participatory forest management system. Improvement of present monitoring and evaluation system of LFLP section is inevitable to make PLF program as a result oriented program.

\section{References}

Agrawal, A. and Ostrom, E. 2001. Collective Action, Property Rights, and Decentralizationin Complementarities and Contradictions. Journal of Forest and Livelihood, 2(1): 1-14

Baral, J. C. and Thapa, Y. 2003. Nepal's Leasehold Forestry for the Poor: The other Side of the Coin, In Timsina, N. P. and H. Ojha Eds. (2004), Case Studies on Equity and Poverty in the Management of Common Property Resources in Nepal. Proceedings of the National Workshop on Management of Common Property Resources and Equity: Exploring Lessons from Nepal, May 28, 2003.

Baral, J.C. 2004. Can Community Forestry Learn from Pro-Poor Leasehold Forestry? A Review. Miscellaneous paper Series.

Baral, J.C. and Thapa, Y. 2004. Nepal's Leasehold Forestry for the Poor: The Other Side of the Coin. Case Studies on the Equity and Poverty in the Management of Common Property Resources in Nepal. Forest Action Nepal, Kathmandu. 
Bhattarai, B. and Dhungana, S. P. 2005. How Can Forests Better Serve the Poor? A Review of Documented Knowledge on Leasehold and Community Forestry in Nepal. Forest Action Nepal and Centre for International Forestry Research.

Bhattarai, B., Ojha, H. and Humagain, Y. 2003. Leasehold forestry, Exclusive Use Right, and Equity: A case study of Charpipal LFUG, Kavre District. Forest Action Nepal, Kathmandu.

Bhattarai, B., Ojha, H. and Humagain, Y. 2005. Is Leasehold Forestry Really a Pro-Poor Innovation in Nepal? Evidences from Kavre District. Journal of Forest and Livelihood, 4(2): 17-30.

Carney, D. 1998. Implementing the Sustainable Livelihood Approach, In: D. Carney (Ed.), Sustainable Rural Livelihood: What Contribution Can We Make? DFID, UK.

Chhetri, R.B. 2006. From Protection to Poverty Reduction: A Review of Forestry Policies and Practices in Nepal. Journal of Forest and Livelihood, 5(1): 66-77.

Dhungel, S. 1997. Legal Aspects of Leasehold Forestry. Seminar on Leasehold Forestry and Forage Development for the Poor, August 24-28, Hills Leasehold Forestry and Forage Development Project, Kathmandu.

Douglas, Z.E. 2000. The Effects of Differing Access to Forest Resources on the Livelihood and Capital Assets of Poor Women in Kavre District, Nepal. BA Thesis. School of Development Studies, The University of East Anglia, United Kingdom.

Fisher, R.J. 1989. Indigenous systems of common property forest management in Nepal, East- West Centre, Environment and Policy Institute. Working Paper No. 18. Honolulu, Hawaii, USA.

Ghimire, K. 2000. The Impact of Differing Access Forest Resources on the Livelihoods and Capital Assets of Poor Women in Makwanpur District, Nepal. Post Graduate Thesis. Indian Institute of Forest Management. Bhopal, India.

GoN. 2007. Interim Plan. Government of Nepal, National Planning Commission, Kathmandu, Nepal.

GoN. 2010. Three Year Plan Approach Paper. Government of Nepal, National Planning Commission. Kathmandu, Nepal.

Grinten, P.V.D. and Dhakal, N.H. 1997. Household Impact Study II Volume: Main Report. Hills Leasehold Forestry and Forage Development Project, Kathmandu, Nepal.

HMGN. 1976. National Forestry Plan. His Majesty’s Government of Nepal, Ministry of Forests and Soil Conservation, Kathmandu, Nepal. 
HMGN. 1988. Master Plan for the Forestry Sector. His Majesty's Government of Nepal, Ministry of Forests and Soil Conservation, Kathmandu, Nepal.

HMGN. 1993. Forest Act. His Majesty’s Government of Nepal, Ministry of Forests and Soil Conservation, Kathmandu, Nepal.

HMGN. 1995. Agriculture Prospective Plan. His Majesty’s Government of Nepal, Ministry of Agriculture and Cooperative, Kathmandu, Nepal.

HMGN. 1995. Forest Regulation. His Majesty’s Government of Nepal, Ministry of Forests and Soil Conservation. Kathmandu, Nepal.

HMGN. 1997-2002. Ninth Plan. His Majesty’s Government of Nepal, National Planning Commission, Kathmandu, Nepal.

HMGN. 2002. Leasehold Forest Policy. His Majesty’s Government of Nepal, Ministry of Forests and Soil Conservation, Kathmandu, Nepal.

HMGN. 2002. Tenth Plan. His Majesty's Government of Nepal, National Planning Commission, Kathmandu, Nepal.

HMGN. 2004. Agriculture Policy. His Majesty's Government of Nepal, Ministry of Agriculture and Cooperatives, Kathmandu, Nepal.

HMGN. 2004. Non Timber Forest Products Policy. His Majesty’s Government of Nepal, Ministry of Forests and Soil Conservation, Kathmandu, Nepal.

IFAD. 2003. Hills Leasehold Forestry and Forage Development Project, Interim Evaluation. Report No 1431-NP. International Fund for Agricultural Development, Rome, Itlay.

IFAD. 2012 (draft). IFAD Country Program Evaluation Debriefing Note. International Fund for Agriculture Development. Rome, Itlay.

Joshi, N. N., Chhetry, M., Karmacharya, M.B. and Karna, B.K. 2000. Impact Assessment of the Hills Leasehold Forestry and Forage Development Project on Vegetation and Social Development in Bhagawatisthan Site, Nepal: Forest Resources and InstitutionsResearch Program (NFRI).

LFLP. 2009. Annual Report. Department of Forest, Leasehold Forestry and Livestock Program, Babarmahal, Kathmandu.

Nightingale, A. J. 2005. The Experts Taught Us All We Know: Professionalization and Knowledge in Nepalese Community Forestry. Antipode, 37(3): 581-604.

Niraula, T. R. 2001. Impact of Leasehold Forestry on Income Generation of the Poor in 
Nepal: A Case Study of Hatiya and Harnamadi VDCs of Makawanpur District in the Central Hills. Central Department of Economics, Tribhuvan University, Kathmandu, Nepal.

NPC. 2005. Impact Evaluation of Hills Leasehold Forestry and Forage Development Project (HLFFDP) (GCP/NEP/049 NET). National Planning Commission in collaboration with UNDP/PRSP, Kathmandu, Nepal.

Ohler, F.M.J. 2000. The Impact of Leasehold Forestry on Livelihoods and Environment. Food and Agriculture Organization of the United Nations, Technical Assistance Phase Two to the Hills Leasehold Forestry and Forage Development Project, Kathmandu, Nepal.

Pandit, B. H. 2009. Effectiveness of Leasehold Forestry to Poverty Reduction. First Report Submitted to Technical Assistant to Leasehold Forestry and Livestock Program. Babarmahal, Kathmandu.

Pandit, B.H. and Thapa, G.B. 2004. Poverty and Resource Degradation in the Mountains of Nepal. Society and Natural Resources, 17:1-16.

Pandit, B.H., Albano, A. and Kumar, C. 2008. Improving benefits to forest-dependent poor: Learning from the best practices of community-based forest enterprises in Nepal. CIIFOR/IFAD Project, Indonesia.

Regmi, B., Albano, A. and Kumar, C. 2008. Improving the livelihoods of the poor and marginalized in Nepal through leasehold forestry and livestock program: A review of institutional constraints and opportunities. Banko Janakari, 18(2):10-17.

Sharma, B. P. 2011. The Welfare Impact of Leasehold Forestry in Nepal. Working paper, No 61-11. South Asian Network for Development and Environmental Economics.

Singh, B. K. 1997. Conflict Management in Leasehold Forestry for the Poor. Seminar on Leasehold Forestry and Forage Development for the Poor, August 24-28, Hills Leasehold Forestry and Forage Development Project, Kathmandu.

TA LFLP. 2011. Outcome study report of Leasehold Forestry and Fivestock Program, Nepal. Study conducted by Leasehold Forestry and Livestock Program (LFLP) \& Technical Assistance for LFLP, FAO Nepal.

TA LFLP. 2012 (draft). Leasehold forest user group categorization: an analysis of the group status. Technical Assistant for Leasehold Forestry and Livestock Program, FAO Nepal.

Yadav, R.P. and Dhakal, A. 2000. Leasehold Forestry for Poor. An Innovative Pro-Poor Program in the Hills of Nepal. Policy Outlook Series No 6. Ministry of Agriculture and Winrock International. Kathmandu. 